\title{
EVOLUTION, WATER BALANCE, POTENTIAL HAZARDS, AND CONTROL OF A PRO-GLACIAL LAKE IN THE FRENCH ALPS
}

\author{
by
}

M. Vallon

(Laboratoire de Glaciologie et Géophysique de l'Environnement, BP 96, 38402 Saint-Martin-d'Hères Cedex, France)

\section{ABSTRACT}

Lake Arsine, a pro-glacial lake in the French Alps, first appeared 30 years ago and has since been growing steadily. In 1985, it reached an area of 5.9 ha, a maximum depth of $39 \mathrm{~m}$, and a volume of $0.8 \times 10^{6} \mathrm{~m}^{3}$. This lake is dammed partially by a glacial moraine and partially by a tongue of dead ice covered by a moraine 1-2 m thick. The glacier calves into the lake, which collects all the melt water from the surrounding glacial area of 250 ha. No open outlet exists and seepage reaches a value of $5 \times$ $10^{6} \mathrm{~m}^{3}$ year $^{-1}$. A 1 year water balance shows that seepage increases rapidly with water level, from less than $0.03 \mathrm{~m}^{3} \mathrm{~s}^{-1}$ to more than $0.75 \mathrm{~m}^{3} \mathrm{~s}^{-1}$ for a rise in water level of $10 \mathrm{~m}$. The seasonal lake-volume fluctuations of $0.5 \times 10^{6} \mathrm{~m}^{3}$ are small compared with the inflow volume of $5 \times 10^{6} \mathrm{~m}^{3}$.

Progressive clogging of the bottom by glacial flour has led to a gradual rise of $8 \mathrm{~m}$ in 16 years in the summer level, while at the same time the height of the dam has decreased by $10 \mathrm{~m}$ due to the melting of dead ice. Consequently, by the end of July 1985 the freeboard was only $2 \mathrm{~m}$ and overflow on to the dead ice was thought likely to occur in the very near future. To eliminate this flood hazard, a $250 \mathrm{~m}$ long channel was dug in an ice-free zone which had been profiled by geophysical prospecting. This work was carried out between 14 April and 13 June 1986 , in order to benefit from the low winter water level.

Geotechnical studies of the moraine have shown that no large landslide is to be feared. A crude model of the waves created by calving shows that the new water level is safe and the channel is capable of handling the maximum likely discharge of $15 \mathrm{~m}^{3} \mathrm{~s}^{-1}$ resulting from the highest possible wave of $3.5 \mathrm{~m}$.

\section{STRUCTURE OF AND RECENT CHANGES IN THE GLACIER}

Arsine Glacier is a small glacier with an area of approximately 250 ha on the north side of the Oisans Range $\left(44^{\circ} 57^{\prime} \mathrm{N}, 6^{\circ} 24^{\prime} \mathrm{E}\right)$. The glacier has never been subjected to regular monitoring and, even though the earliest observations go back to 1890 (Prince R. Bonaparte, 1891), little is known of its evolution over the last century. With a copious supply of rock debris from the north face of the ridge running from the Pic des Agneaux at $3663 \mathrm{~m}$ to the Pic de Neige Cordier at $3613 \mathrm{~m}$ the glacier, which is largely blanketed, has built up an extensive system of moraines. These have been described by Allix (1928) and subsequently also by Volle (unpublished). Below a moraine ridge $100 \mathrm{~m}$ high, generally attributed to advances of the glacier in the nineteenth century (Lliboutry, 1965; Vivian, 1967) and still poorly colonized by vegetation, there extends a zone of about 30 ha in area of moraine hummocks, which are much older than the ridge, are entirely covered by alpine meadow, and have the morphological characteristic of a rock glacier (Fig. 1).

The thickness of the glacier has been determined gravimetrically (Echevin, unpublished) and by seismic reflection (Créancier and Gelbert, unpublished). Two reflections can generally be seen, and analysis of the velocity of the reflected waves using the $t^{2}\left(\Delta^{2}\right)$ method shows that the ice $\left(V_{\mathrm{p}}=3650 \pm 100 \mathrm{~m} \mathrm{~s}^{-1}\right)$ rests on a layer of about $30 \mathrm{~m}$ of moraine $\left(V_{\mathrm{p}}=2000 \pm 200 \mathrm{~m} \mathrm{~s}^{-1}\right)$. The density of this basal moraine $\left(\rho \approx 2000 \pm 200 \mathrm{~kg} \mathrm{~m}^{-3}\right)$ can be estimated by a comparison of seismic and gravity measurements.

Two detailed $(1: 2000)$ maps of the surface dating from August 1969 and July 1985 were compared by survey. The changes in level over 15 years have been considerable and very irregular, from -35 to $+15 \mathrm{~m}$ depending on the area (Fig. 2). There has been swelling of the left western half of the glacier by between 10 and $16 \mathrm{~m}$, whereas the surface for an area $200 \mathrm{~m}$ wide and $400 \mathrm{~m}$ long on the right-hand edge, upward of the lake, has fallen by about $10 \mathrm{~m}$. The mean change in volume in the area investigated has been very small $\left(-0.20 \pm 0.09 \mathrm{hm}^{3}\right)$, equivalent to an average fall in level of $-0.34 \pm 0.15 \mathrm{~m}$. This change in the geometry of the glacier has been accompanied by a change in its dynamics. The surface velocities of the ice along the two flow lines, one ending at the calving snout (a), the other $150 \mathrm{~m}$ to the west (b), are shown in Figure 3. Although the dynamics of the glacier appeared to be little affected by the presence of the lake in 1970, flow along the flow lines ending in the lake became very extensive about $250 \mathrm{~m}$ up-glacier from the calving snout in 1985. Conversely, for the flow lines located more to the west, the current flow of the glacier is more compressive than it was 15 years ago. Analysis of measurements of the vertical component of the velocity of the ice shows that the changes observed between 1969 and 1985 (thinning of the right-hand half of the glacier tongue, thickening of the left-hand half) continued between 1985 and 1987. Arsine Glacier has thus been undergoing an advance for the last $10-15$ years. It would seem, however, that this advance has only slightly slowed down the progressive extension of the lake. The mean extension of the lake was of the order of $10 \mathrm{~m} \mathrm{a}^{-1}$ between 1952 and 1969, and of the order of $7.5 \mathrm{~m} \mathrm{a}^{-1}$ between 1969 and 1985 (Fig. 4).

\section{THE LAKE}

The lake of Arsine Glacier is not shown on any map, or was its existence reported by any observer, between the eighteenth century and 1929 (see Vivian (1967) and Edouard (unpublished)). The lake appeared for the first time in a photograph by the Institut Géographique National (La Grave-Chorge Expedition, 1952) and was already extensive since its area was $0.7 \mathrm{ha}$. Its subsequent development can be followed regularly from aerial surveys between 1960 and 1986 and from ground surveys made in 1969 and 1985. The changes in both length and surface area are shown in Figure 4. It can be estimated by extrapolating from its observed development that the lake probably appeared between 1940 and 1948, a period when the mass balance in the Alps was very negative (Martin, 1977) and was accompanied by a general retreat of the glacier fronts. It has also been possible to estimate the volume of the lake at 


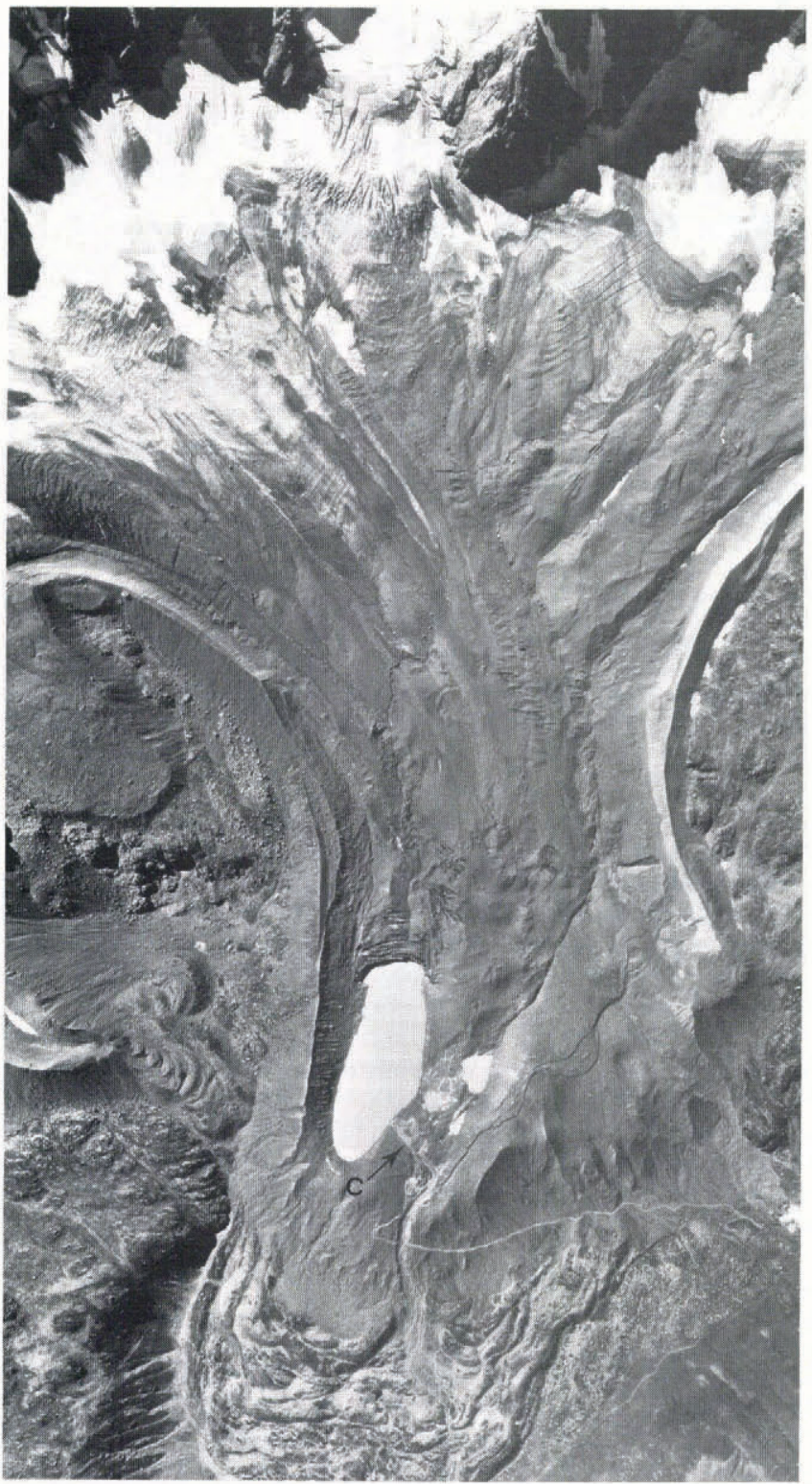

Fig. 1. Lake Arsine and the glacier in September 1986. C = artificial channel cut in spring 1986.

different periods from three sets of unpublished soundings (Tournier; Edouard; Créancier and Gelbert) (Fig. 4). The dimensions of the lake at the times for which the most complete studies are available (1969 and 1985) are summarized in Table I.

The lake (Fig. 5) is bounded on the east by a lateral moraine $50-70 \mathrm{~m}$ high with a very steep slope of 0.90 . On the north, the terminal moraine, which is indented by a small saddle at an elevation $2470 \mathrm{~m}$, itself the trace of a former outflow from the glacier has a very much gentler

TABLE I. DIMENSIONS OF LAKE ARSINE

\section{August 1969}

\section{July 1985}

$\begin{array}{lcr}\text { Length } & 296 \mathrm{~m} & 393 \mathrm{~m} \\ \text { Width } & 180 \mathrm{~m} & 227 \mathrm{~m} \\ \text { Area } & 33900 \mathrm{~m}^{2} & 59100 \mathrm{~m}^{2} \\ \text { Maximum depth } & \approx 32 \mathrm{~m} & 39 \mathrm{~m}^{3} \\ \text { Volume } & 531800 \mathrm{~m}^{3} & 800900 \mathrm{~m}^{3} \\ \text { Level } & 2450 \mathrm{~m} & 2457.5 \mathrm{~m}\end{array}$

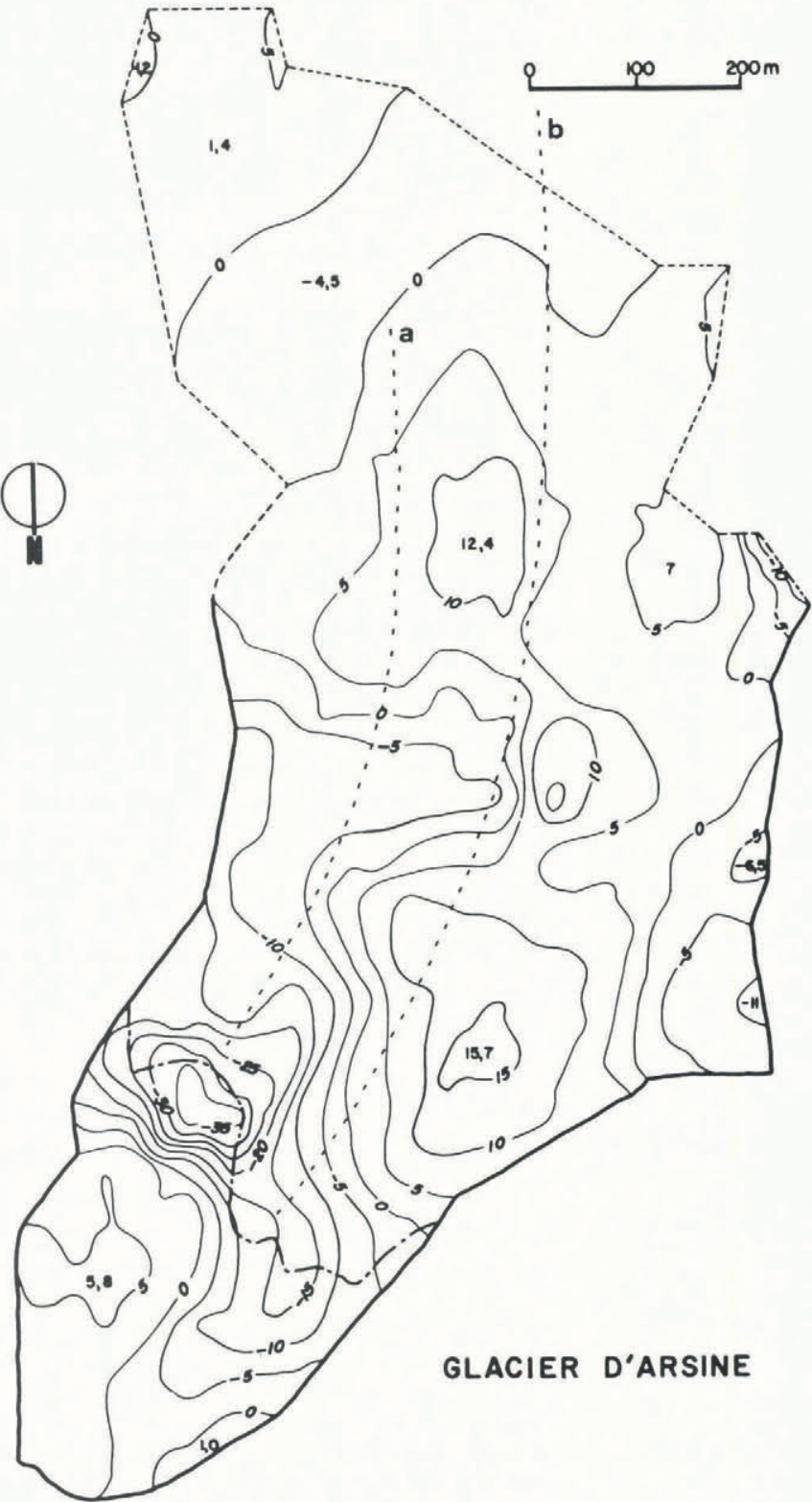

Fig. 2. Changes in level of glacier (m) between August 1969 and July 1985. Surface topography of glacier was extremely irregular so changes in level were observed at 400 points (equally spaced about $35 \mathrm{~m}$ apart) and smoothed (running average over $10000 \mathrm{~m}^{2}$ ). (Dotted lines $\equiv$ flow lines of Figure 3.)

relief with slopes of the order of 0.3-0.4. A seismic section through this moraine is shown in Figure 6. Resistivity surveys also show that it includes neither frozen ground nor an ice core. In 1969, the western boundary was formed by the blanketed glacier whose surface lay about $15 \mathrm{~m}$ above the level of the lake. In this area the fall in the level of the glacier between 1969 and 1985 varied between 5 and $15 \mathrm{~m}$ and small lakes appeared in the late 1970s which it is thought joined the main lake between 1981 and 1983. At the end of July 1985, an area of dead ice about $100 \mathrm{~m}$ wide which formed the north-western side of the lake projected no more than $2-3 \mathrm{~m}$ above the maximum level of the lake. The limits of this residue of dead ice have been determined from around ten seismic refraction lines, the thickness of the ice layer seems to be of the order of $10 \mathrm{~m}$ as calculated from resistivity measurements, and the thickness of the moraine cover calculated from seismic refraction and resistivity measurements is between 1 and $2 \mathrm{~m}$. A reflection at a depth of about $60 \pm 10 \mathrm{~m}$ probably identifies the position of the bedrock. Detailed soundings of the lake by 12 transverse profiles and six longitudinal profiles were taken on 20 and 26 July 1985, when the lake was close to its maximum level of $2457.5 \mathrm{~m}$. The soundings were located with an accuracy of the order of 1-2 m 


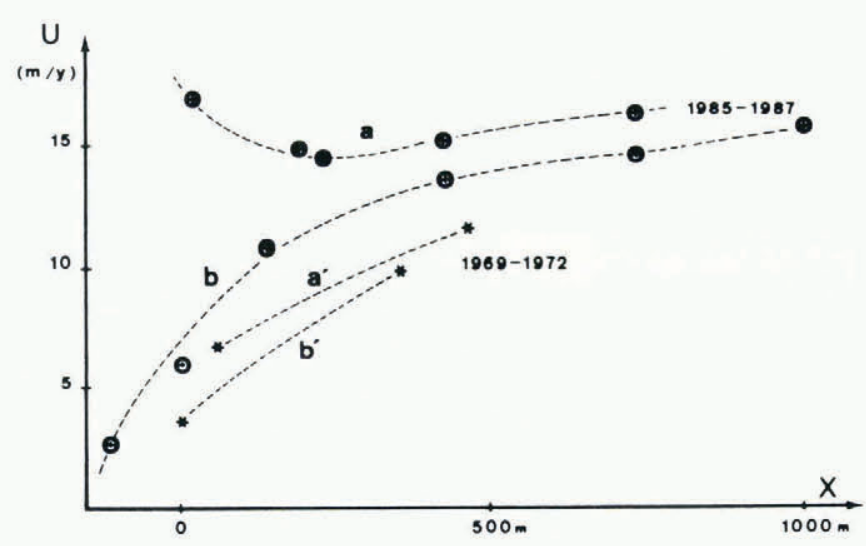

Fig. 3. Surface velocity along two flow lines. a and $a^{\prime}=$ the flow line ending at the calving face. $b$ and $b^{\prime}=$ flow line in the centre of the glacier (cf. Fig. 2).

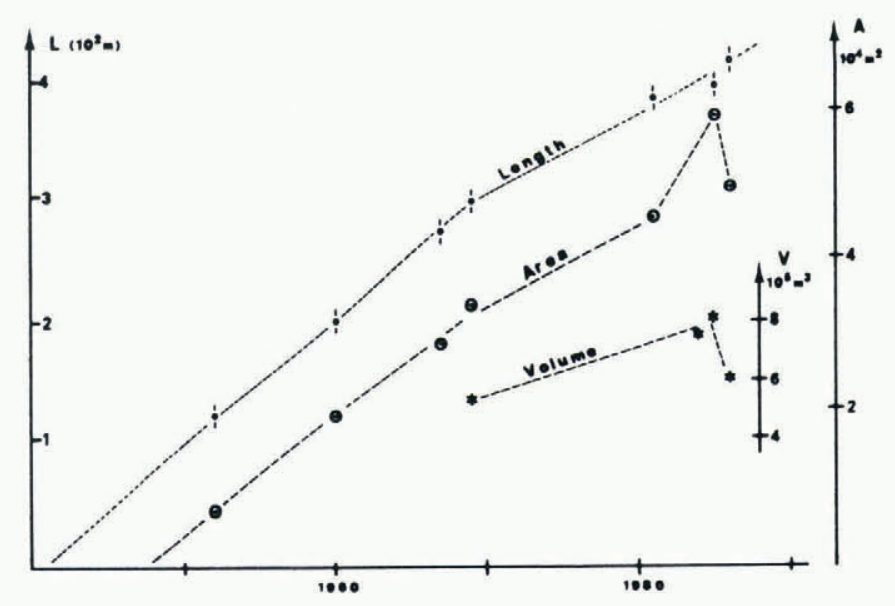

Fig. 4. Changes in Lake Arsine between 1952 and 1986. Reduction in surface area and volume between 1985 and 1986 resulted in artificial drainage.

through intersection of the position of the echo sounder from two theodolites every $30 \mathrm{~s}$, that is every $25-30 \mathrm{~m}$ ). The volume of the lake is found to be of the order of $801000 \mathrm{~m}^{3}$. According to the formulae proposed by Hakanson (1981), this volume is accurate to within $\pm 13 \%$, taking into account the density of the soundings and the method of integration used.

The nature of the bottom of the lake is unknown. Extrapolation of the depth of the bedrock determined by seismic reflection and refraction below the glacier, up-glacier from the lake, below the terminal moraine, and under the area of dead ice, nevertheless suggests that the lake rests on morainic material, the bedrock probably lying $10-20 \mathrm{~m}$ below the bottom of the lake.

\section{HYDROLOGICAL BALANCE}

The lake has no surface outlet and as evaporation is negligible most losses are due to seepage. The lake level varies over a considerable range, of the order of $10-12 \mathrm{~m}$, in the course of a year (Fig. 7), and it rises very quickly when the snows melt in the months of May-July. On 26 May 1986, Villiot (Villiot and others, 1986) observed a rise of $380 \mathrm{~mm}$ in a period of $24 \mathrm{~h}$ of fine weather $\left(0^{\circ} \mathrm{C}\right.$ isotherm around $3700 \mathrm{~m}$ ), and the maximum level of $2457.5 \mathrm{~m}$ was reached towards the end of July. From the beginning of August the lake level began to drop regularly, although inputs were still considerable, being of the order of $0.5-0.8 \mathrm{~m}^{3} \mathrm{~s}^{-1}$, to reach the minimum level of $2447 \mathrm{~m}$ towards the end of the winter.

The hydrological balance for the lake is given by

$$
\mathrm{d} V / \mathrm{d} t=Q+P+C-I-E
$$

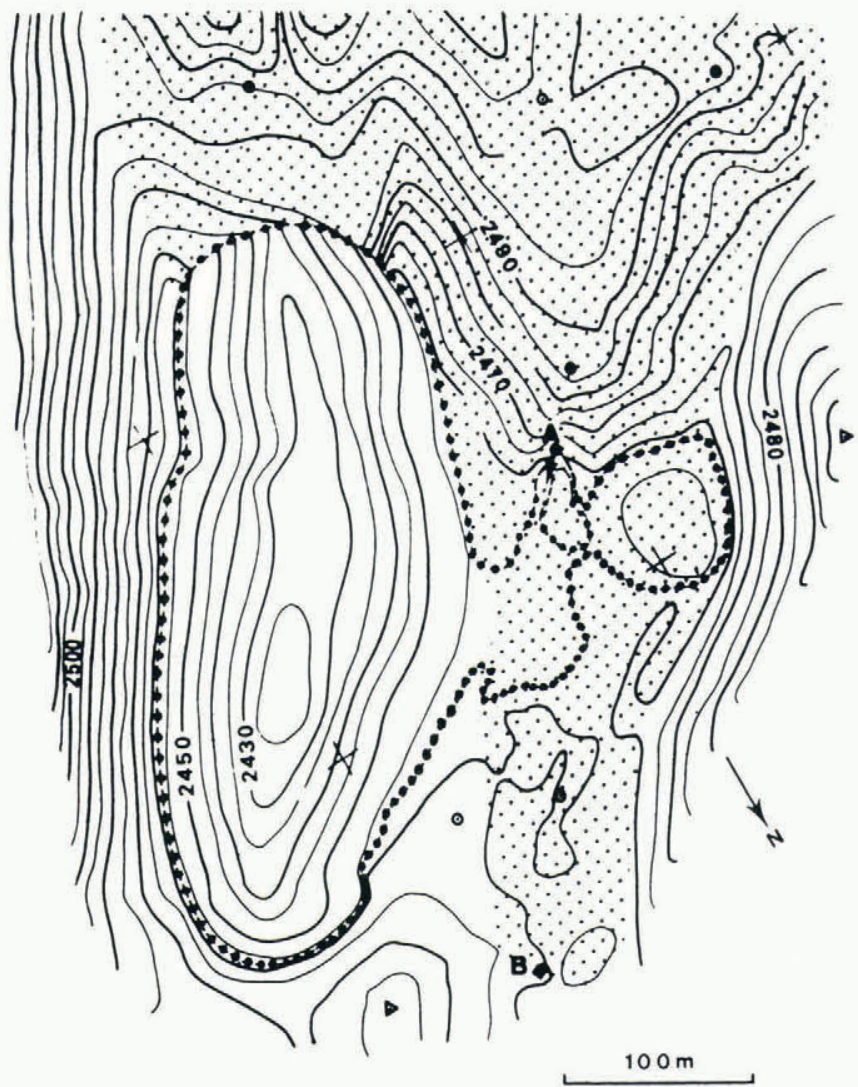

Fig. 5. Limits of lake on 20 July 1985 (dotted line) A is resurgent stream, B is mountain hut; shaded area is glacier; dead-ice zone extend from $\mathrm{A}$ to $\mathrm{B}$.

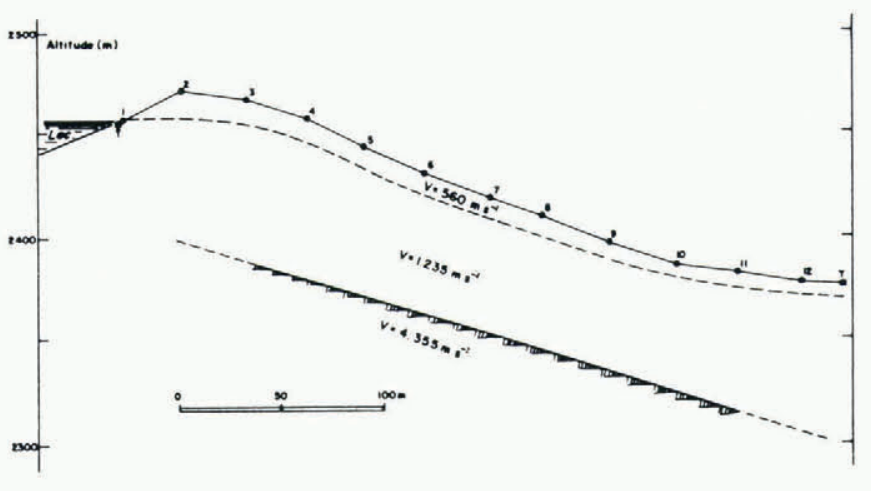

Fig. 6. Cross-section through terminal moraine (seismic refraction). $1-12=$ seismometers; $T=$ shot points.

where $\mathrm{d} V$ is the change in volume of lake, $Q$ is the input of melt water from glacier, $P$ is the precipitation, $C$ is calving, $I$ is seepage, and $E$ is evaporation.

In August 1969, Tournier (unpublished) measured evaporation of the order of $0.17 \mathrm{~mm} \mathrm{~h}^{-1}$ during the day and $0.02 \mathrm{~mm} \mathrm{~h}^{-1}$ during the night by use of evaporation troughs floating on the lake. For the lake as a whole, this is equivalent to an average loss of $1.5 \times 10^{-3} \mathrm{~m}^{3} \mathrm{~s}^{-1}$, assuming that day and night are of equal duration. The calving snout of the glacier is grounded and average calving can be estimated from the velocity in the vicinity of the calving face $\left(u f \approx 16-17 \mathrm{~m} \mathrm{a}^{-1}\right)$ and the changes in the position, $x$, of the front of width $L \approx 100 \mathrm{~m}$ and mean height $h \approx 40 \mathrm{~m}$ to be

$$
C=(u f-\mathrm{d} x / \mathrm{d} t) L h .
$$

We are of the opinion that calving takes place only 


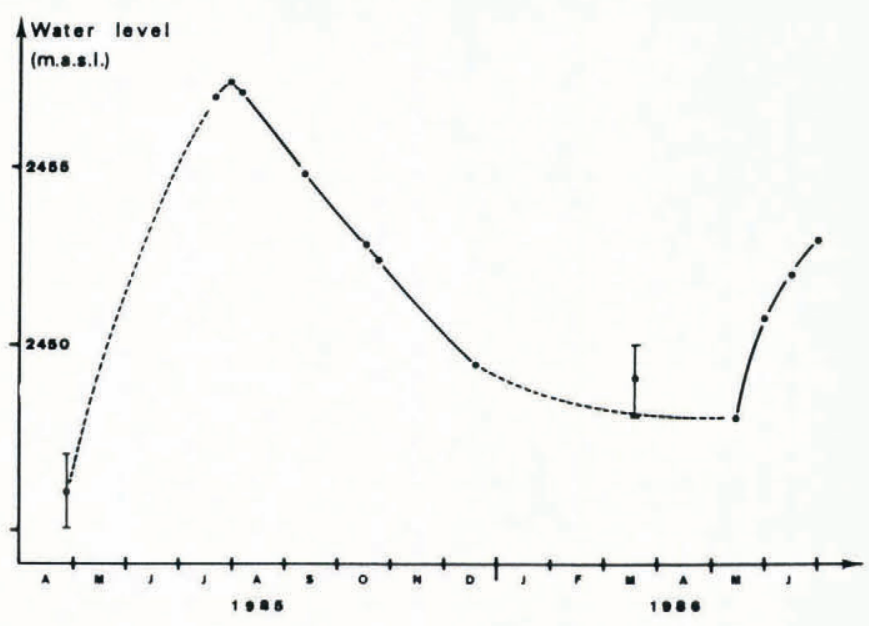

Fig. 7. Changes in lake level between April 1985 and June 1986.

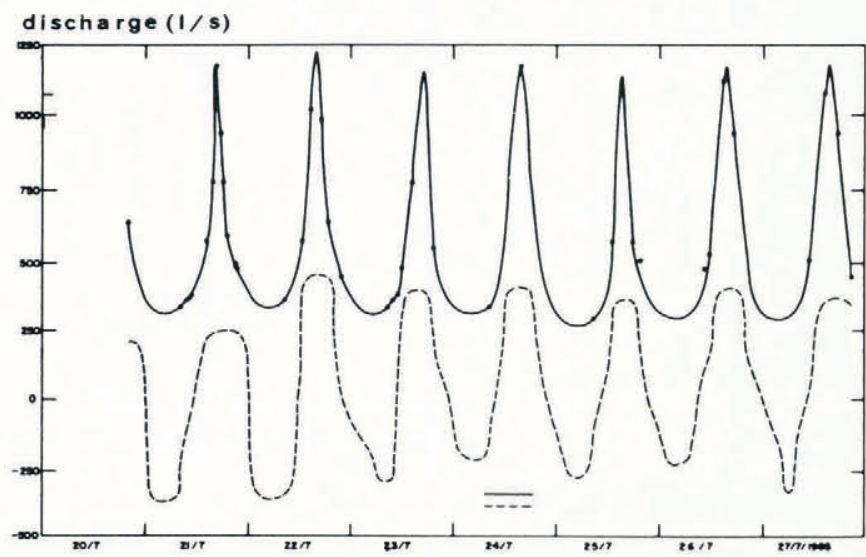

Fig. 8. Flow in resurgent stream (solid line) and changes in lake volume (dotted line $=\mathrm{d} V / \mathrm{d} t)$ from 20-27 July 1985.

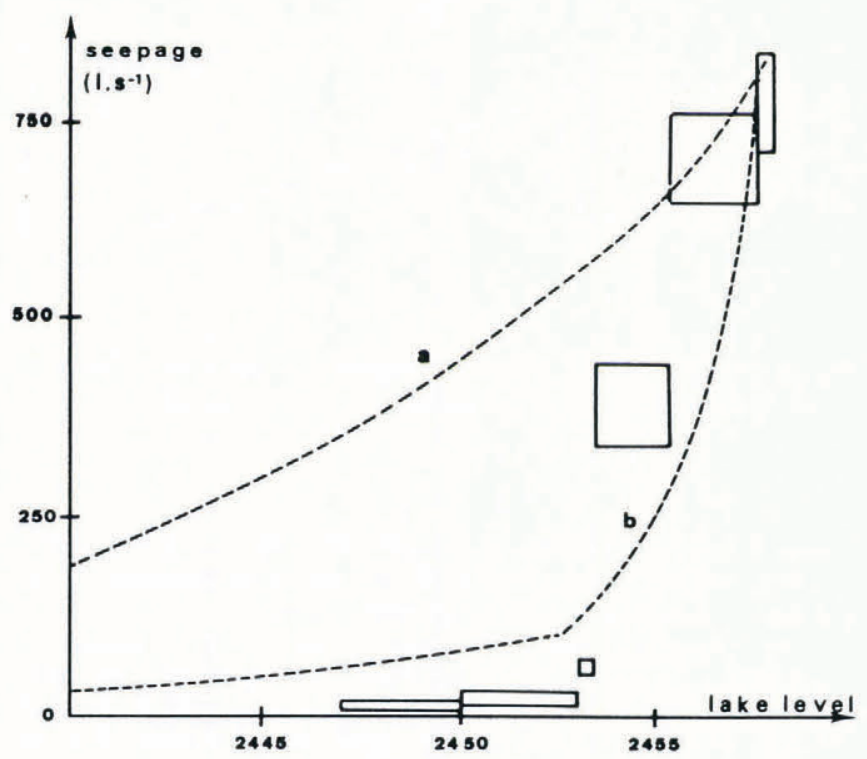

Fig. 9. Losses due to seepage in relation to lake level. Calculated values from hydrological balance. For JulySeptember (calculated seepage $>0.25 \mathrm{~m}^{3} \mathrm{~s}^{-1}$ ) main part of uncertainty originates from estimation of $Q$ (we assume an uncertainty of $\pm 10 \%$ on ablation). For October-April (seepage $<0.1 \mathrm{~m}^{3} \mathrm{~s}^{-1}$ ), main part originates from inaccuracy on $P( \pm 30 \%)$ and $\mathrm{d} V( \pm 1 \mathrm{~m}$ for level of lake in March 1986). a is constant permeability seepage model; $b$ is seepage model with permeability reduced $100 x$ below $2452.5 \mathrm{~m}$. when the surface of the lake is free from ice, that is for about $150 \mathrm{~d}$ from June to October. No trace of any winter calving has been observed at the foot of the ice cliff in spring (April-May). The layer of ice covering the lake is folded into two or three anticlinal ridges $1-2 \mathrm{~m}$ high over about $30 \mathrm{~m}$ from the front as a result only of the thrust due to winter movement of the glacier. Depending on whether the figure for the retreat of the front observed between 1985 and $1986\left(\mathrm{~d} x / \mathrm{d} t=-20 \pm 10 \mathrm{~m} \mathrm{a}^{-1}\right)$ or a more accurate average value $\left(\mathrm{d} x / \mathrm{d} t=-6.7 \pm 0.6 \mathrm{~m} \mathrm{a}^{-1}\right)$ for measurements between 1969 and 1985 is taken, the input to the lake by calving $(C)$ is of the order of $7-11 \times 10^{-3}$ $\mathrm{m}^{3} \mathrm{~s}^{-1}$ during the period from June to October. For $90 \mathrm{~d}$ between July and September 1985, precipitation in the Oisans Massif was extremely low, being less than $0.5 \mathrm{~m}^{3} \mathrm{~m}^{-2}$. This is equivalent to an average input to the lake of the order of only $3 \times 10^{-4} \mathrm{~m}^{3} \mathrm{~s}^{-1}$. Assuming that the lake collects all the run-off from the 250 ha of the glacier, precipitation during the summer of 1985 would have added about $1.5 \times 10^{-2} \mathrm{~m}^{3} \mathrm{~s}^{-1}$ to the lake. We have also assumed that the melting of precipitation in the form of snow between October and December is negligible and that precipitation on to the lake is the only significant factor after 1 October 1985. The sum of the three terms in the hydrological balance $(C+P-E)$ is thus of the order of $2-2.5 \times 10^{-2} \mathrm{~m}^{3} \mathrm{~s}^{-1}$ in summer and $0.3-0.7 \times 10^{-2} \mathrm{~m}^{3} \mathrm{~s}^{-1}$ in autumn and winter $(C=E=0 ; P=1.5 \pm 0.5 \mathrm{~m}$ of water for a total of $210 \mathrm{~d}$ ).

The lake is fed by resurgence of the melt water from the glacier (Fig. 5). The daily distribution of this input was observed between 20 and 27 July 1985 to be about $0.25 \mathrm{~m}^{3} \mathrm{~s}^{-1}$ at $09.00 \mathrm{~h}$ and about $1.2 \mathrm{~m}^{3} \mathrm{~s}^{-1}$ by $16.00 \mathrm{~h}$ (Fig. 8). The mean flow of $0.52 \pm 0.10 \mathrm{~m}^{3} \mathrm{~s}^{-1}$ during this period represented about $66 \%$ of the ablation observed on the glacier. It is unlikely that this resurgence is the only input of melt water into the lake from the glacier because there is a high probability of hidden inputs from the basal moraine and from a subglacial stream draining the righthand side of the glacier with its outlet directly below the level of the lake. We have therefore assumed that all the melt water from the glacier did in fact reach the lake. Because ablation of the ice was observed regularly from July to December 1985 , we can estimate $Q$ for the whole of the summer and autumn period of 1985.

Changes in the volume of the lake are known on a time-scale of a few hours between 20 and 27 July (Fig. 8), and on the time-scale of months from August 1985 to April 1986 (Fig. 7). The outflow due to seepage which can be deduced from the above observations varies from 0.2 to $0.80 \mathrm{~m}^{3} \mathrm{~s}^{-1}$ depending on the period. These changes are shown in relation to the level of the water surface in Figure 9. As soon as the level of the lake exceeds $2453 \mathrm{~m}$ seepage increases very rapidly, changing by about $0.15 \mathrm{~m}^{3} \mathrm{~s}^{-1}$ when the lake level rises $1 \mathrm{~m}$. Below the level of $2453 \mathrm{~m}$, on the other hand, seepage is of the order of $0.01-0.03 \mathrm{~m}^{3} \mathrm{~s}^{-1}$ and is independent of the lake level, bearing in mind that there is uncertainty concerning the amount of input. As the surface area of the lake varies by about $30 \%$ between the minimum and the maximum levels and the head position likewise varies considerably from one point to another from 0 to $37 \mathrm{~m}$ and from one time to another so that a $10 \mathrm{~m}$ change in level has been recorded, considerable changes in flow in relation to water level are not surprising. It would seem, however, that seepage does not only depend on the above parameters.

Assuming that the permeability $(K)$ of the lake bottom is constant, a detailed sounding (isobaths every $2.5 \mathrm{~m}$ ) enables us to calculate the seepage (I). Darcy's law, $\mathrm{d} I=K \mathrm{~d} S h / e$ (where $K$ is the permeability of the ground of thickness $e, h$ is the pressure in metres of water, $\mathrm{d} S$ is the cross-sectional area) can be written:

$$
I=K / e \int h \mathrm{~d} S .
$$

We have shown the calculated seepage for two models in Figure 9:

(a) Constant permeability for all the lake bottom with $K / e$ $=1 \times 10^{-6} \mathrm{~m} \mathrm{~s}^{-1} \mathrm{~m}^{-1}$ of water.

(b) $K / e=18 \times 10^{-6} \mathrm{~m} \mathrm{~s}^{-1} \mathrm{~m}^{-1}$ of water between the altitudes 2457.5 and $2452.5 \mathrm{~m}$. K/e $=0.18 \times 10^{-6} \mathrm{~m} \mathrm{~s}^{-1} \mathrm{~m}^{-1}$ of water between $2452.5 \mathrm{~m}$ and the lake bottom $(2422 \mathrm{~m})$. 
If permeability were constant, the lake would virtually disappear in the course of the winter, becoming reduced to less than 1 ha around the $2430 \mathrm{~m}$ level, $15 \mathrm{~m}$ below the lowest level observed in spring. It must therefore be assumed that the permeability of the lake bottom varies by a factor of approximately 100 within the year, the base of the lake bottom, which is clogged by glacier flour, having very low permeability below level $2453 \mathrm{~m}$.

In calculating the seepage, particularly during the winter period, we have neglected any inputs originating from the layer of basal moraine as it gradually drains in the course of the winter. In fact, we have no data on extent, porosity, and permeability of the basal moraine, and the hydraulic gradient which could be used to estimate this source of hidden inputs. We can only estimate the maximum order of magnitude of these inputs using extreme assumptions. If it is assumed that the basal moraine drains entirely by the end of the winter and that during the summer the moraine stores all the glacier melt water which does not appear in the resurgent stream (approximately 34\% of the ablation, or $1.8 \times 10^{6} \mathrm{~m}^{3}$ ), then between September and April $(240 \mathrm{~d})$ drainage of the moraine would supply an average flow of $0.087 \mathrm{~m}^{3} \mathrm{~s}^{-1}$. If this is the case, seepage when the lake level lies between 2447 and $2453 \mathrm{~m}$ would be of the order of $0.10-0.12 \mathrm{~m}^{3} \mathrm{~s}^{-1}$. Even this figure for winter inputs to the lake, which we feel to be very much overestimated, does not alter the general shape of the graph of seepage in relation to lake level (Fig. 9) and does not invalidate the previous conclusion that the permeability of the lake bottom appears to vary by a factor of about 100 at an altitude of $2453 \mathrm{~m}$ a.s.l.

In October 1985, when the lake level was around $2452 \mathrm{~m}$, we were able to observe that the deposit of glacial flour on and between the blocks of moraine became very much thicker in altitudes towards $2453-2454 \mathrm{~m}$ a.s.l. In 1969 the maximum level of the lake stabilized around $2450 \mathrm{~m}$ and Tournier (unpublished) estimated seepage to be between 0.34 and $0.46 \mathrm{~m}^{3} \mathrm{~s}^{-1}$. Seepage losses for the same level in 1985 were ten times smaller. We only find losses of the order of $0.40 \mathrm{~m}^{3} \mathrm{~s}^{-1}$ when the water level is in the vicinity of $2454 \mathrm{~m}$. It can therefore be assumed that the limit between the permeable zone and the impermeable zone has risen by about $4 \mathrm{~m}$ in 16 years, a rise equivalent to $0.25 \mathrm{~m} \mathrm{a}^{-1}$. The average rise in the maximum lake level is very much greater than this, being $2450 \mathrm{~m}$ in 1969 and $2457.5 \mathrm{~m}$ in 1985 (or approximately $0.5 \mathrm{~m} \mathrm{a}^{-1}$ ). However, in 1969 only part of the glacier melt water reached the lake, a surface stream of a few tenths of $\mathrm{m}^{3} \mathrm{~s}^{-1}$ running along the left-hand edge of the glacier escaped directly across the small saddle cut into the terminal moraine to the west of the hut (Fig. 5)

\section{ANALYSIS OF RISK AND ITS CONTROL}

Ice or moraine-dammed lakes are potentially dangerous (Post and Mayo, 1971; Lliboutry and others, 1977; Haeberli, 1983; Mochalov and Stepanov, 1986). In the case of Lake Arsine, a number of possibilities likely to result in overflow can be envisaged:

(a) Movement of the water following a major input of material into the retained lake by calving from the glacier or slippage of the moraine. Geotechnical investigation of the moraine (Antoine and Monnet, unpublished) has demonstrated that it is satisfactorily stable, only surface slips mobilizing small volumes being likely to occur. From an examination of the glacier snout, it has been estimated that the maximum probable calving would be of the order of $5000 \mathrm{~m}^{3}$. Modelling of the wave produced (Vila, unpublished) has provided an estimated wave height of around $3.5 \mathrm{~m}$, sufficient to overflow on to the area of dead ice and perhaps initiate erosion of this part of the dam.

(b) Without any falls of material, extrapolation of the rise in the maximum water level (about $0.5 \mathrm{~m} \mathrm{a}^{-1}$ between 1969 and 1985) and melting of the stagnant ice dam (also of the order of $0.5 \mathrm{~m} \mathrm{a}^{-1}$ ) suggests that the lake will overflow within a period of about 2 years. Experience with the artificial drainage of Lake Bogatyr by means of a channel cut into frozen ground containing ice lenses (Nurkadilov and others, 1986) shows that there is rapid spontaneous deepening of a channel in this type of material.
By the end of 1985 it was obvious that the lake would overspill within the next 3 years. The possibility that a torrential mud flow might occur, mobilizing a large volume of moraine material, could not be ruled out. When warned of this situation, those responsible for public safety (the Prefecture of Hautes-Alpes) met with the main parties involved including district mayors, regional authorities in charge of agriculture, construction, public safety, and the Ecrins National Park, in order to decide on a strategy. An investigation of different possible lines of action - a warning and evacuation plan, passive defence by means of a protective embankment, pumping out the lake, raising the natural dam - was carried out in spring 1986. It was decided to stabilize the level of the lake at $2453 \mathrm{~m}, 4.5 \mathrm{~m}$ below the maximum level achieved the previous summer by creating an artificial channel in the moraine. This work, which was organized by the Hautes-Alpes authority for the restoration of mountain areas (Van Effanterre, unpublished), had to be carried out as soon as possible in order to take advantage of the low winter level of the lake. It took 2 weeks (14-30 April 1986) to get the earth-moving equipment to an elevation of $2450 \mathrm{~m}$ under particularly unfavourable climatic conditions, but despite this the channel was completed on 13 June 1986 and the lake began to drain on 29 June 1986

\section{ACKNOWLEDGEMENTS}

Field work and data evaluation were performed with the assistance of L. Augustin, C. Carle, G. Cognet, M Créancier. D. Donnou. J.L. Edouard. C. Gelbert, E. Lefebvre, J. Perrin, F. Rapetto, L. Reynaud, M. Ricard, and C. Vincent. This study was financed by the Laboratoire de Glaciologie et Geophysique de l'Environnement of the CNRS and a contract from the Hautes-Alpes R.T.M. We are grateful to CEMAGREF of Grenoble for authorizing reproduction of the air photograph (Fig. 1).

\section{REFERENCES}

Allix, A. 1928. L'Oisans, étude géographique. Paris, Armand Colin

Antoine, P. and J. Monnet. Unpublished. Détermination de la stabilité de la moraine limitant à l'Est le lac d'Arsine. Rapport IRIGM (Institut de Recherche Interdisciplinaire en Géologie et Mécanique), Grenoble, 1986.

Bonaparte, R. 1891. Les variations périodiques des glaciers français. Annuaire du C.A.F., 17-18.

Créancier, M. and C. Gelbert. Unpublished. Etude du glacier et du lac d'Arsine. Rapport de stage. Ecole Nationale d'Hydraulique, Grenoble, 1985.

Echevin, M. Unpublished. Prospection gravimétrique du glacier d'Arsine. (Thése de $3 \mathrm{e}$ cycle, Université de Grenoble, 1987.)

Edouard, J.L. Unpublished. Observations nouvelles sur trois lacs juxtaglaciaires dans les massifs du Haut-Dauphiné Section de Glaciologie de la Société Hydrotechnique de France, 1985.

Effenterre, C. van. Unpublished. Lac du glacier d'Arsine; étude de risque et travaux de protection. Sociéte Hydrotechnique de France. Section de Glaciologie, 1987.

Haeberli, W. 1983. Frequency and characteristics of glacier floods in the Swiss Alps. Ann. Glaciol., 4, 85-90.

Hảkanson, L. 1981. A manual of lake morphometry. Berlin, Springer Verlag.

Lliboutry, L. 1965. Traité de glaciologie. Tome 2. Glaciers. variations du climat, sols gelés. Paris, Masson.

Lliboutry, L., B. Morales Arnao, A. Pautre, and B. Schneider. 1977. Glaciological problems set by the control of dangerous lakes in Cordillera Blanca, Peru. J. Glaciol. 18(79), 239-290.

Martin, S. 1978. Analyse et reconstitution de la série des bilans annuels du glacier de Sarennes, sa relation avec les fluctuations du niveau de trois glaciers du Massif du Mont Blanc (Bossons, Argentiére, Mar de Glace.) Z Gletscherkd. Glazialgeol., 13(1-2), 1977, 127-153.

Mochalov, V.P. and B.S. Stepanov. 1986. Glyatsial'nyye 
pavodki i metody bor'by [Glacial floods and methods of their control]. Mater. Glyatsiol. Issled., 58, 104-109. [English text p. 216-219.]

Nurkadilov, Z.K., A. Yu. Khegay, and N.V. Popov. 1986. Iskusstvennoye aporozhneniye proryvoopasnogo ozera u podnozhiya pul'sirushchego lednika [Artificial draining of an outburst-dangerous lake at the foot of a surging glacier]. Mater. Glyatsiol. Issled., 58, 108-113. [English text p. 220-221.]

Post, A. and L.R. Mayo. 1971. Glacier dammed lakes and outburst floods in Alaska. U.S. Geol. Surv. Hydrol. Invest. Atlas, HA 455, 85-90.

Tournier, P. Unpublished. Caractères du lac du glacier
d'Arsine. (Thése de $3 e$ cycle, Université de Grenoble, 1971.)

Vila, J.P. Unpublished. Etude des effets provoqués par la chute de séracs dans le lac d'Arsine. Rapport CEMAGREF. Divison de Nivologie, 1986.

Villiot, J., J.C. Cocheteau, and C. van Effenterre. 1986. Des travaux forestiers au glaciers d'Arsine. Arborescences 6.

Vivian, R. 1967. Fiches des glaciers français: le glacier d'Arsine. Rev. Géogr. Alp., 55(2), 397-400.

Volle, L. Unpublished. Morphologie glaciaire sur le versant Nord du massif de l'Oisans. DES Institut de Géographie, Grenoble, 1967. 